\title{
$\mathrm{Ni}$ および C 無添加生体用 Co-29Cr-6Mo 鍛造合金の 乾式摩擦摩耗挙動*1
}

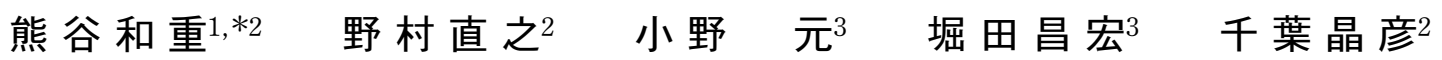 \\ 1岩手大学大学院工学研究科物質工学専攻 \\ 2岩手大学工学部福祉システム工学科 \\ 岩手県工業技術センター
}

J. Japan Inst. Metals, Vol. 70, No. 4 (2006), pp. 265-274

Special Issue on Materials Technology for Improving QOL C) 2006 The Japan Institute of Metals

\section{Dry Friction and Wear Behavior of Forged Co-29Cr-6Mo Alloy without Ni and C Additions for Implant Applications}

\author{
Kazushige Kumagai ${ }^{1, * 2}$, Naoyuki Nomura ${ }^{2}$, Tsukasa Ono ${ }^{3}$, Masahiro Hotta ${ }^{3}$ and Akihiko Chiba ${ }^{2}$ \\ ${ }^{1}$ Department of Material Science, Graduate School of Engineering, Iwate University, Morioka 020-8551 \\ ${ }^{2}$ Department of Welfare Engineering, Faculty of Engineering, Iwate University, Morioka 020-8551 \\ ${ }^{3}$ Iwate Industrial Research Institute, Morioka 020-0852
}

\begin{abstract}
A dry wear behavior of a forged $\mathrm{Co}-\mathrm{Cr}-\mathrm{Mo}$ alloy without $\mathrm{Ni}$ and $\mathrm{C}$ additions have been investigated using a ball-on-disc type wear testing machine with an alumina ball in ambient air. The wear factor of the $\mathrm{Co}-\mathrm{Cr}-\mathrm{Mo}$ forged alloy without $\mathrm{Ni}$ and $\mathrm{C}$ additions (hereafter, designated the forged alloy) shows negative contact load dependence. The coefficient of friction decreases with increasing contact load. Worn surfaces are hardened during the wear tests, forming oxide films. This results from significantly high work hardening rate of the forged alloy, caused by the strain-induced martensitic transformation from an fcc $-\gamma$ phase to an hcp $-\varepsilon$ phase, which contributes to the improvement in the dry wear resistance.

Wear mechanisms of the forged alloy are discussed on the basis of Hertzian contact theory and observations of the wear scars formed on the alloy disc and the alumina ball surfaces. It is considered that the dominant wear mechanism of the forged alloy is the mild adhesive wear, though the extrinsic abrasive wear mediated by the wear debris, i.e., third-body abrasive wear, is exerted as an extrinsic wear mechanism. In addition, it is suggested that a delamination wear resulting from the fatigue fracture likely occurs under the present dry wear condition.
\end{abstract}

(Received September 22, 2005; Accepted November 11, 2005)

Keywords: biomaterials, medical implants, cobalt-chromium-molybdenum alloy, forged cobalt-chromium-molybdenum alloy, wear, wear resistance, wear mechanism

\section{1. 緒言}

整形外科分野および歯科分野では, 疾病や事故により失っ た生体組織やその部位の機能を回復させるために, 生体組織 を人工材料で置換する方法が行われる．このような人工材料 はバイオマテリアル(生体材料) と呼ばれ，金属，高分子，セ ラミック等が使用されている. 中でも金属材料は他の材料に 比べて, 引張強度, 疲労強度, 勒性などの機械的特性に優れ ているので, 人工関節や義歯床といった硬組織代替機能材料 として既に広く使用されている1). 特に Co- Cr-Mo 合金は耐 食性や耐疲労性のみならず，耐摩耗特性に優れているため, 人工関節のような過酷な条件下で使用されるデバイスの材料 として有望である ${ }^{1-5)}$.

鋳造材の合金組成は ASTM F75 で規格化され，最大 1

*1 Mater. Trans. 46(2005) 1578-1587 に掲載

*2 岩手大学大学院生 (Graduate Student, Iwate University) mass\%までの Ni を含むことが許されている．この Ni 添加 は鋳造性を向上させる目的で行われるが，それ以外にも塑性 加工性向上という効果がある. 塑性加工性が向上することで 組織制御が可能になり, Co- $\mathrm{Cr}-\mathrm{Mo}$ 合金の延性, 強度の改 善が期待できる.しかし, 近年 Ni によるアレルギーが懸念 されており6,7), Ni 無添加で高強度特性を有する生体用 $\mathrm{Co}-$ $\mathrm{Cr}-\mathrm{Mo}$ 合金の開発が求められている. Ni を含まない $\mathrm{Co}^{-}$ $\mathrm{Cr}-\mathrm{Mo}$ 合金は塑性加工性に乏しいので, 加工熱処理による 再結晶化法を用いた組織制御が困難であることから，Ni フ リーの生体用 Co-Cr-Mo 合金の高強度化に問題を有してい る.

従来 $\mathrm{Ni}$ 無添加の $\mathrm{Co}-\mathrm{Cr}-\mathrm{Mo}$ 合金は鍛造による組織制御は 困難であるとされていたが，我々は加工熱処理を改良するこ とで, 比較的容易に微細粒組織を有する $\mathrm{Ni} フ リ ー \mathrm{Co}-\mathrm{Cr}-$ Mo 合金を開発することに成功した。これによると， $3 \mu \mathrm{m}$ 程度の平均結晶粒径に調整された $\mathrm{Ni}$ フリー $\mathrm{Co}-\mathrm{Cr}-\mathrm{Mo}$ 合金 の引張強度 $(1050 \mathrm{MPa})^{8)}$ は，これまでの報告されているど 
の $\mathrm{Co}-\mathrm{Cr}-\mathrm{Mo}$ 合金のもの $(655 \mathrm{MPa})^{9)}$ よりに比べて高い值を 示すことが明らかにされている.この開発合金の特徴として, $\mathrm{Ni}$ フリーであると同時に, 高温鍛造性を向上させるため C 添加していないことも挙げられる. 一方, $\mathrm{Ni}$ 添加抢よび $\mathrm{C}$ 添加は $\mathrm{Co}-\mathrm{Cr}-\mathrm{Mo}$ 合金の積層欠陥エネルギーの上昇に効果 があり，Cを 0.2 mass\%程度含有した $\mathrm{Co}-\mathrm{Cr}-\mathrm{Mo}$ 合金の結 晶構造は $\gamma$ 相が安定化されている10,11). これに対して, 本研 究で扱う $\mathrm{Ni}$ 抢よび $\mathrm{C}$ 無添加の $\mathrm{Co}-\mathrm{Cr}-\mathrm{Mo}$ 合金は $\gamma$ 相が不 安定であるため, 容易にひずみ誘起マルテンサイト変態によ り $\varepsilon$ 相に変態する傾向を有する ${ }^{12)}$. このような相安定性が, 力学特性に及ぼす効果について知ることは重要である.

人工関節材料にとって引張強度のみならず, 耐摩耗性も重 要であるが, $\mathrm{Ni}$ および C 無添加の組織制御された $\mathrm{Co}-\mathrm{Cr}-$ Mo 合金の摩耗特性を調べた研究は未だ報告されていない.

そこで, 本研究の目的は, 高温鍛造を用いて粒径制御, 組 織制御した高強度 $\mathrm{Ni}$ 抢よび $\mathrm{C}$ 無添加 $\mathrm{Co}-\mathrm{Cr}-\mathrm{Mo}$ 合金の乾 式摩擦・摩耗特性を調べ，その摩耗機構に関して知見を得る ことである．アルミナを用いた乾式摩耗試験は， Co- $\mathrm{Cr}-\mathrm{Mo}$ 合金の摩耗機構を考察する際の基礎的知見を与える。なた, $\mathrm{Ni}, \mathrm{C}$ フリー Co-Cr-Mo 鍛造合金の摩耗機構を解明するこ とで, 高耐摩耗性 $\mathrm{Co}-\mathrm{Cr}-\mathrm{Mo}$ 合金開発の指針となる知見を 得ることが期待される.

\section{2. 実 験 方 法}

\section{1 試料作製}

純度 99.92 mass \%の Co， 99.99 mass \%の Cr， 99.90 mass $\%$ の $\mathrm{Mo}$ を出発原料とし, 公称組成が $\mathrm{Co}-29 \mathrm{Cr}-6 \mathrm{Mo}$ (mass\%) となるように秤量し, 高周波真空誘導溶解炉によ り $5 \mathrm{~kg}$ のインゴットを溶製した．得られたインゴットを大 気中で $1523 \mathrm{~K}$ で $12 \mathrm{~h}$ の均質化熱処理を施した後, $1273 \mathrm{~K}$ 以上の温度に保持して高温鍛造を施した．鍛造比は断面積比 で $62 \%$ とした。鍛造試料の化学分析組成を，ASTM F75, Stellite 6Bの合金組成とともに Table 1 に示す。作製した鍛 造合金には $\mathrm{Ni}$ が 0.02 mass\%程度検出されたが，これは原 料に不可避的に混入する不純物に由来するものと考えられる. ASTM F75 にて規定されている $\mathrm{Co}-\mathrm{Cr}-\mathrm{Mo}$ 合金では 1 mass $\%$ 程度の $\mathrm{Ni}$ の含有が許容されていることから考え, 本 研究で作製した合金試料を低 $\mathrm{Ni}$ 鍛造合金 (以後, 単に本鍛 造合金と称する) と呼ぶ。C も検出されたが，これは脱酸処 理用に添加した未反応 Cの一部が残ったものである.

\section{2 組織観察}

本鍛造合金の構成相の同定は微小部 X 線回折装置 (RIGAKU RINT-2550V/PC) を用いて行った．X 線源は $\mathrm{CrK} \alpha$ で，測定には $\phi 0.1 \mathrm{~mm}$ のコリメーターを使用した． $\mathrm{X}$
線照射方向は垂線方向に対し $30^{\circ}$ である.X 線回折パターン は各試験片に対し，少なくとも 8 回測定し代表的なものを 採用した。本研究では Sage らの方法 ${ }^{13)} に$ 習い, 式 (1)より $\gamma$ 相と $\varepsilon$ 相の体積分率を算出した.

$$
\frac{x}{1-x}=\frac{1}{4} \cdot \frac{1.85}{0.27} \cdot \frac{I_{(200) \gamma}}{I_{(10 \overline{1} 1) \varepsilon}}
$$

ここで， $x$ は $\gamma$ 相の体積分率， $I_{(200) \gamma}$ および $I_{(10 \overline{1} 1) \varepsilon}$ はそれぞ れ fcc $(200) \gamma$ および hcp $(10 \overline{1} 1) \varepsilon$ のピークの積分強度である.

平均結晶粒径は光学顕微鏡組織から評価した. 組織観察試 料は＃1200 までエメリー研磨し, 機械研磨による表面加工 層を除去するために電解研磨を施した。電解研磨溶液に 10 $\mathrm{vol} \% \mathrm{H}_{2} \mathrm{SO}_{4}+90 \mathrm{vol} \% \mathrm{CH}_{3} \mathrm{OH}$ 混合液を用いた. 電解条件は 電圧 $6 \mathrm{~V}$, 浸漬時間 30-50 s である.

摩耗試験後の摩耗痕内部の観察および解析には $\mathrm{X}$ 線マイ クロアナライザー (EPMA), 微小部 X 線回折装置を使用し た。またマイクロビッカース硬度計を用いて，摩耗痕の硬さ を測定した．このとき押し込み荷重は表面加工硬化層が無視 できる $9.8 \mathrm{~N}$ とした.

\section{3 摩擦摩耗試験}

ワイヤーカット放電加工機を用いて, 直径 $30 \mathrm{~mm} \times$ 厚さ $5 \mathrm{~mm}$ に切り出した円盤状試料を＃1200 なでのエメリー研 磨を行った後， $0.05 \mu \mathrm{m}$ の $\mathrm{SiO}_{2}$ 砥粒を用いて鏡面仕上げを 施し, 摩擦摩耗試験片とした。このときの表面粗さは, 算術 平均粗さ $\mathrm{Ra}$ で評価すると $\mathrm{Ra}<0.05 \mu \mathrm{m}$ であった．本研究 で用いた摩擦摩耗試験片の表面は，すべてこの粗さになるよ うに仕上げた。摩擦摩耗試験はボールオンディスク型摩耗試 験機 (RHESCA FRP-2000)を用いて行った. 試験環境は乾 式であり, 荷重 : 4.9-49 N, 滑り距離 : $10^{4} \mathrm{~m}$, 滑り速度 : $0.5 \mathrm{~m} / \mathrm{s}$ の条件で行った．相手材には直径 $4.8 \mathrm{~mm}$ のアルミ ナボールを使用した. 摩擦・摩耗試験後, 試験片の質量損失 から次式に基づき摩耗率 $\omega$ および比摩耗量 $\omega_{\mathrm{s}}$ を算出した.

$$
\begin{aligned}
& \omega=\frac{M_{\text {loss }}}{L \cdot \rho} \\
& \omega_{\mathrm{s}}=\frac{M_{\mathrm{loss}}}{W \cdot L \cdot \rho}
\end{aligned}
$$

ここで, $M_{\text {loss }}$ : 質量損失 $[\mathrm{kg}], W$ : 荷重 $[\mathrm{N}], L:$ すべり距 離 $[\mathrm{m}], \rho:$ 試験片の密度 $\left[\mathrm{kg} / \mathrm{m}^{3}\right]$ である.

\section{3. 実 験 結 果}

\section{1 光学顕微鏡組織と $\mathrm{X}$ 線回折}

Fig. 1 に本鍛造合金の光学顕微鏡組織を示す. 得られた組 織は鍛造ままのものであるが，ほぼ等軸結晶粒であることか ら高温鍛造中に再結晶したものと考えられる. 平均結晶粒径 は $47 \mu \mathrm{m}$ であった. 粒内には細かいストライエーションが

Table 1 Chemical composition of alloys.

\begin{tabular}{lcccccccccccc}
\hline & $\mathrm{Co}$ & $\mathrm{Cr}$ & $\mathrm{Mo}$ & $\mathrm{Ni}$ & $\mathrm{Fe}$ & $\mathrm{W}$ & $\mathrm{Mn}$ & $\mathrm{Si}$ & $\mathrm{C}$ & \\
\hline The forged alloy & Bal. & 27.84 & 5.88 & 0.02 & & & & 0.01 & 0.028 & 0.0085 & 0.0009 \\
ASTM F75 & Bal. & $27.0-30.0$ & $5.0-7.0$ & $<1.0$ & $<0.75$ & & $<1.0$ & $<1.0$ & $<0.35$ \\
Stellite 6B & Bal. & $28.0-32.0$ & $<1.5$ & $<3.0$ & $<3.0$ & $3.5-5.5$ & $<2.0$ & $<2.0$ & $0.9-1.4$ \\
\hline
\end{tabular}




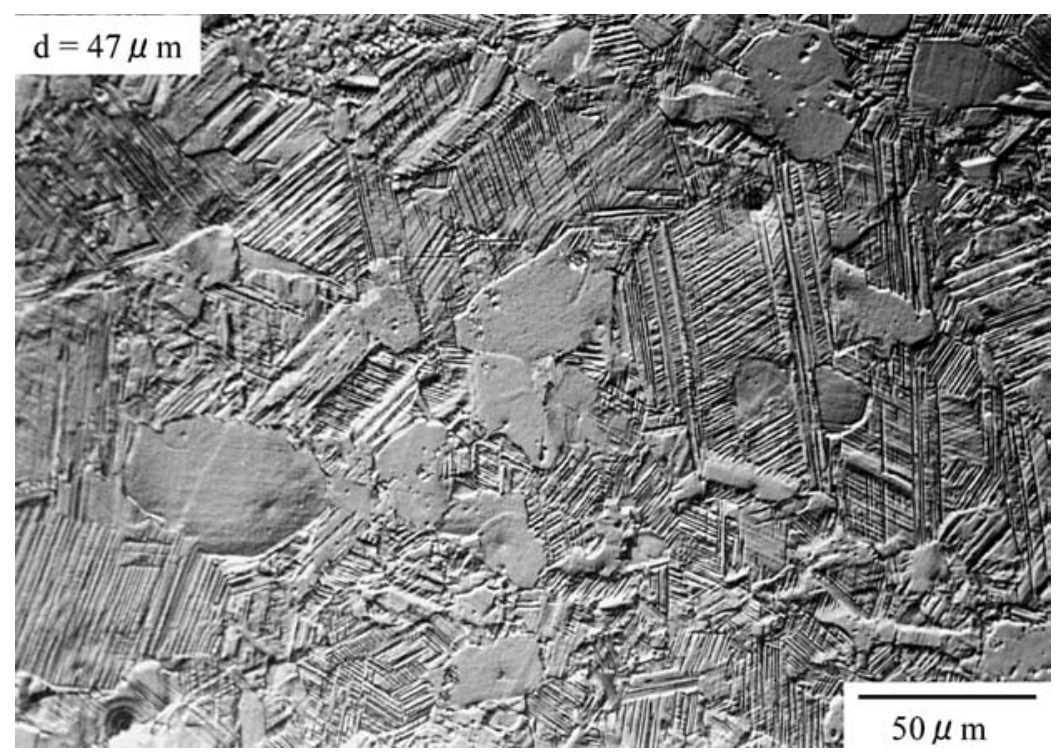

Fig. 1 Optical microstructure of the forged $\mathrm{Co}-\mathrm{Cr}-\mathrm{Mo}$ alloy.

a)
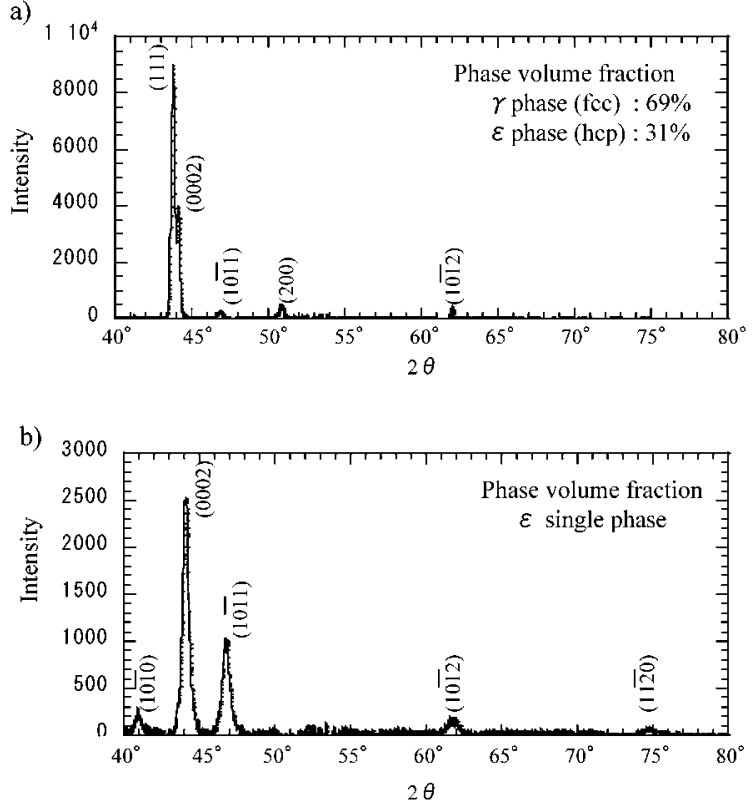

Fig. 2 X-ray diffraction profiles of the forged alloy. (a) Asforged alloys, (b) the worn scar after wear test.

認められた。

Fig. 2 は摩耗試験前後に抢けるディスク試験片の X 線回 折パターンである。(a)は摩耗試験前のもので，(b)は摩耗 試験後の摩耗痕内部のものである. Fig. $2(\mathrm{a})$ より，鍛造合 金の組織は $\gamma$ 相 (fcc) と $\varepsilon$ 相(hcp)の 2 相共存組織であること が分かる. $\gamma$ 相および $\varepsilon$ 相の体積分率はそれぞれ $69 \%$ およ び $31 \%$ あ゙あ．この組織は鍛造作業終了直後に水焼き入れ して得られたので, X 線回折パターン中の $\varepsilon$ 相は非等温マル テンサイトであると考えられる. 光学顕微鏡組織に見られる ストライエーションは $\gamma / \varepsilon$ の異相境界もしくは非等温マルテ ンサイトのバリアント境界であると推測される．Fig. 2(b) より, 摩耗試験前は $\gamma, \varepsilon$ の 2 相組織であったものが, 摩耗 試験後は $\varepsilon$ 単相に変化していることが分かった.

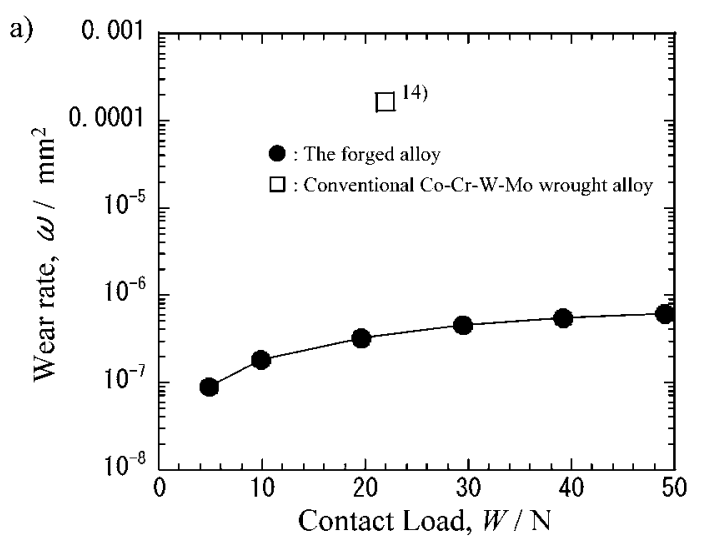

b)

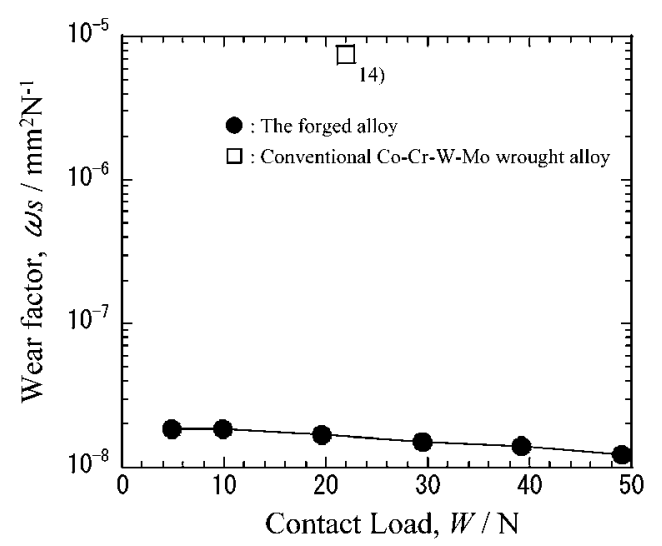

Fig. 3 Wear rate (a) and wear factor (b) of the forged alloy as a function of contact load.

\section{2 摩擦摩耗試験結果}

Fig. 3 (a) 打よび(b)はそれぞれ本鍛造合金における摩耗 率, 比摩耗量の荷重依存性を示す。比較のために他の $\mathrm{Co}^{-}$ $\mathrm{Cr}-\mathrm{Mo}$ 合金のデータを Cooper ら ${ }^{14)}$ の論文より引用し並べ て示す. Cooper らのデータは高炭素 $\mathrm{Co}-\mathrm{Cr}-\mathrm{W}-\mathrm{Mo}$ 合金 (Stellite 6B)のもので, 本研究と同様アルミナボールを用い た摩擦摩耗試験結果である. Cooperらの試験条件は接触荷 
重 $22 \mathrm{~N}$, 滑り速度 $0.87 \mathrm{~m} / \mathrm{s}$ である. Fig. 3(a)より鍛造合金 では接触荷重増加に伴い摩耗率はわずかに増加する。摩耗率 はおよそ $10^{-7} \mathrm{~mm}^{2} / \mathrm{N}$ であり, Stellite $6 \mathrm{~B}$ の摩耗率に比べ 約 2-3 桁少ないことが分かる. 一方, Fig. 3(b) より比摩耗 量についても比較した結果, Stelite $6 \mathrm{~B}$ に比べ本鍛造合金は 約 2 桁以上少ないことが分かる. 本鍛造合金の比摩耗量は 荷重の増加に伴い，緩やかに減少する，以上の結果より，本 鍛造合金の摩耗率ならびに比摩耗量が少ないことから，低 $\mathrm{Ni}$ および低 $\mathrm{C}$ 組成を有し, 組織制御された鍛造合金の耐摩 耗性は著しく高いことが分かる.

Fig. 4 は，本鍛造合金における摩擦係数の接触荷重依存性 を示す. 鍛造合金の摩擦係数は接触荷重増加に伴い $0.34-$ 0.29 にわずかに減少する. Stellite $6 \mathrm{~B}$ の摩擦係数は 0.35 で あることから Stellite $6 \mathrm{~B}$ に比べ, 本鍛造合金の摩擦係数は わずかに低いことが分かる.

\section{3 摩耗痕内部の組織観察}

Fig. 5 にディスク試験片の摩耗痕の二次電子線像を示す. (a) は摩耗痕の外観であり，(b) 抢よび (c)はそれぞれ同一箇 所のエッジ部抢よび内部の拡大図である. 図中の矢印はアル ミナボールの運動方向を示している.ディスク試験片の摩耗 痕内部には，アルミナボールの運動方向に沿った細かい溝が 存在する.その溝は細く鋭いものから比較的幅広のものまで 多様に存在している. 摩耗痕内部には, 摩耗痕を横断する継 ぎ目のようなステップが認められる. そのステップを Fig. 5 (c)に拡大して示す。このステップは幾層かが積み重なっ た構造に見える。さらに Fig. 5(b)より丸印で囲んだ摩耗痕 外縁部にはアルミナボールとの摩耗試験中に生じたと推測さ れる組織(すべり線)が観察された。

Fig. 6 はディスク試験片における摩耗痕内部の反射電子線 像および特性 X 線像である。（a)が反射電子線像 (凹凸像) で，(b)-(e)はそれぞれ Co, Cr， Al および O の特性 X 線像 である。摩耗痕内部にアルミナボールの運動方向に沿った, 細長く盛り上がった摩耗生成物が認められる. 各元素の特性 $\mathrm{X}$ 線像を照合すると, Co の特性 X 線像の抜けたところで $\mathrm{O}$ の特性 X 線像が強くなっている。一方, $\mathrm{Cr}$ と Mo の特性 X

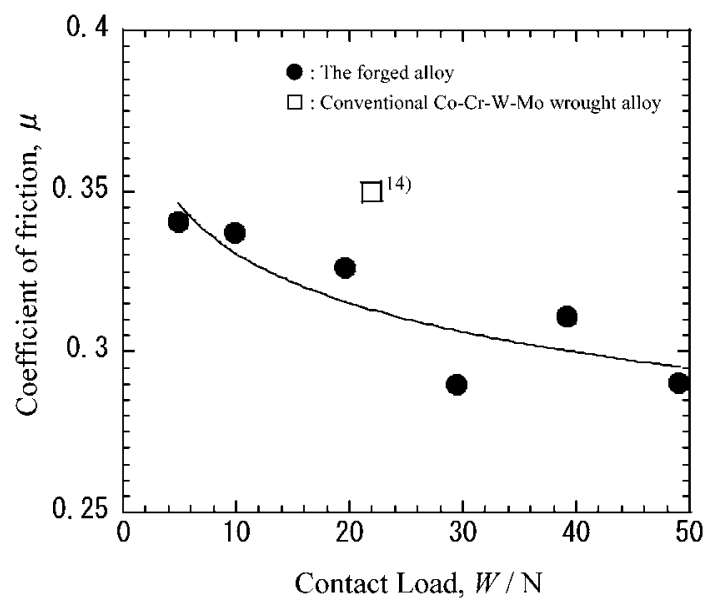

Fig. 4 Coefficient of friction of the forged alloy as a function of contact load.
線像は全面に均一に分布していることから，この摩耗生成物 には Co が欠乏し， O が多量に含まれていることが分かる. この摩耗生成物には Cr および Mo が多く存在するが，アル ミナボールの移着を意味する $\mathrm{Al}$ は存在しない。したがっ て，この摩耗生成物は $\mathrm{Cr}, \mathrm{Mo}$ の酸化物であることが分かる.

Fig. 7 (a) および (b) はそれぞれ $9.8 \mathrm{~N}$ および $49 \mathrm{~N}$ の接触荷 重で摩耗試験した後の摩耗痕内部の SEM 像である. 酸化物 と考えられる黒色の筋状模様が，接触荷重が大きくなること で，より高密度に形成される傾向が認められる．このことか ら, 接触荷重が大きくなると摩耗表面層の形成は摩耗率, 摩
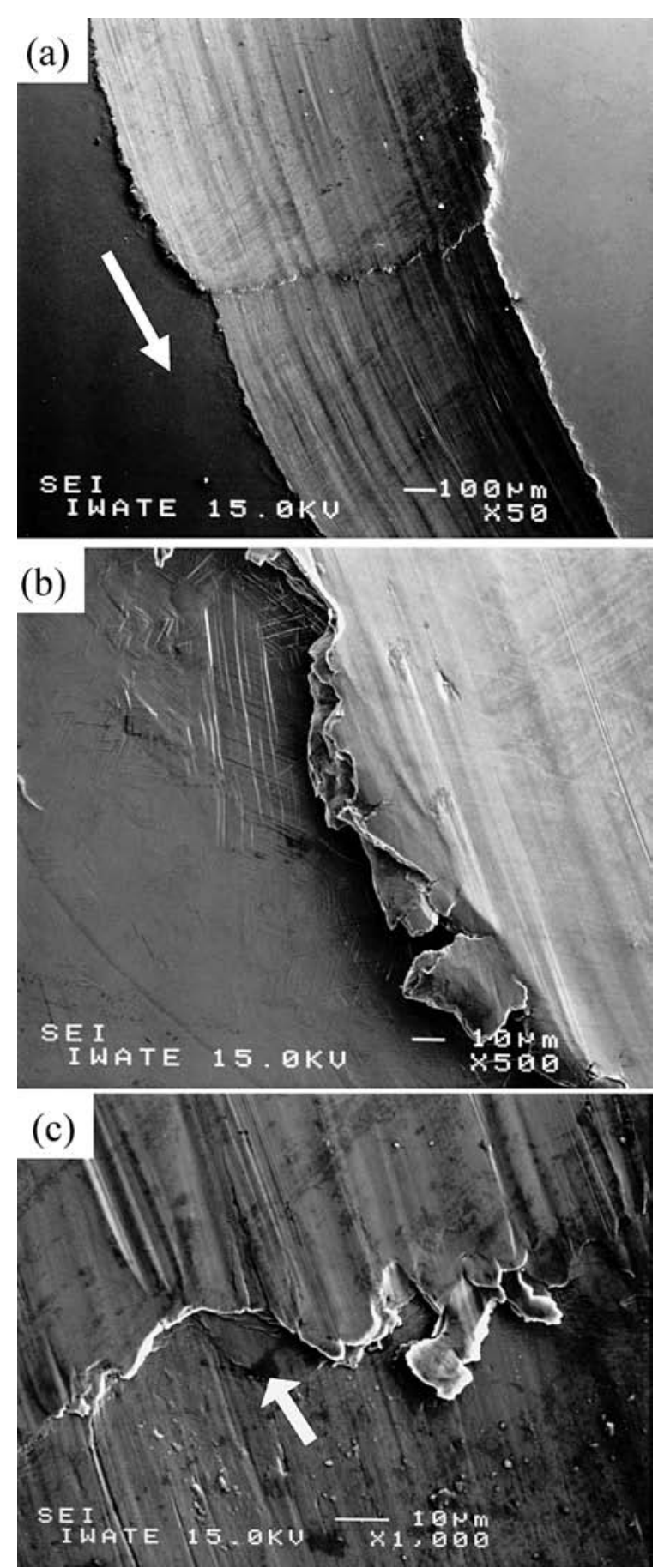

Fig. 5 SEM micrographs of wear scar of the forged alloy at the contact load of $9.8 \mathrm{~N}$. (a) Wear scar, (b) the edge and (c) the step. 

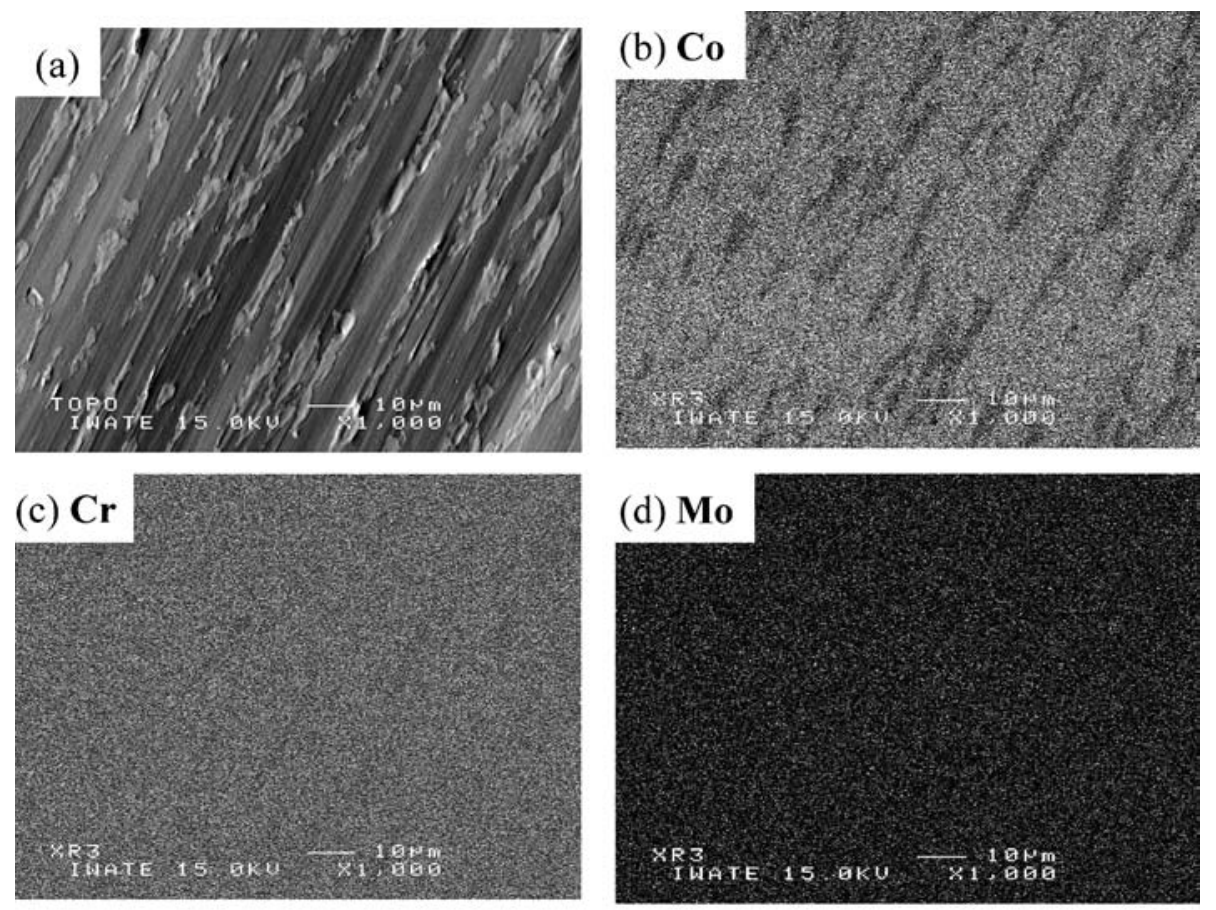

(d) Mo
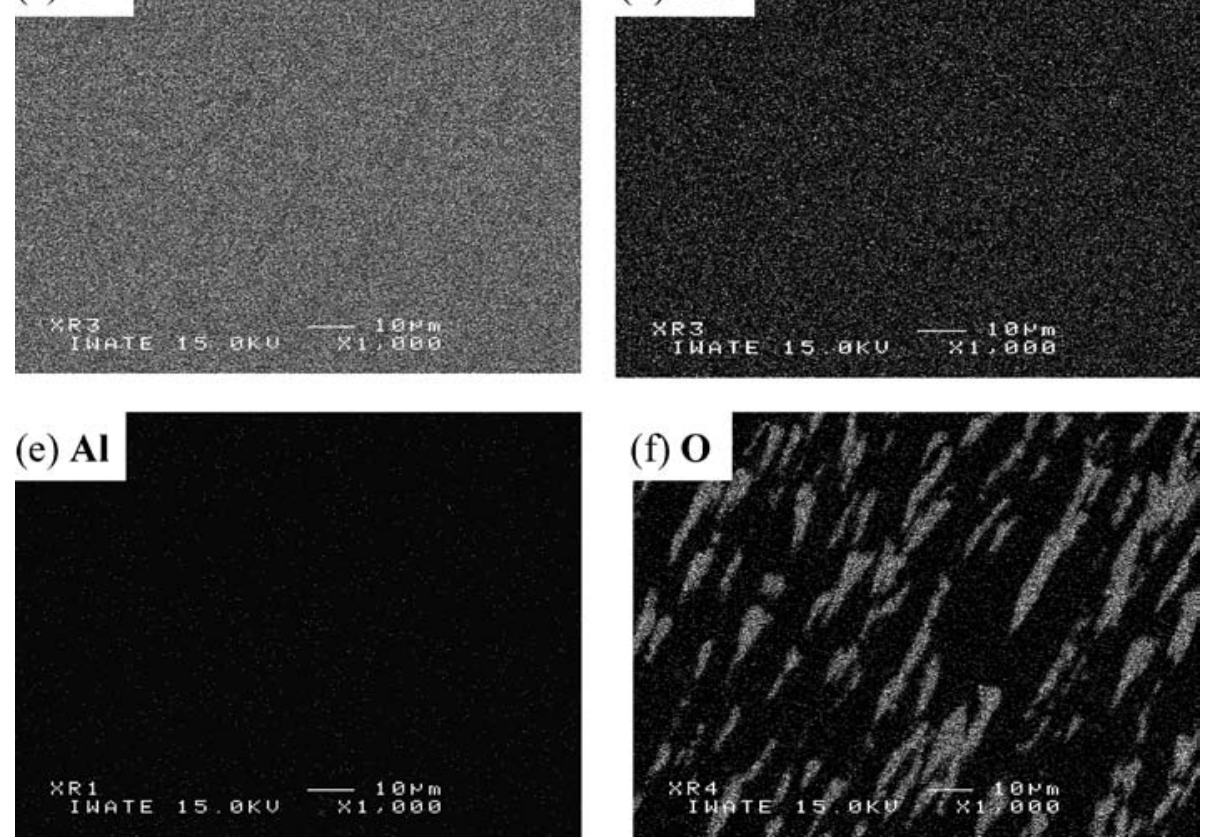

Fig. 6 Backscattered electron micrograph (a) and X-ray maps of (b) $\mathrm{Co}$, (c) $\mathrm{Cr}$, (d) $\mathrm{Mo}$, (e) $\mathrm{Al}$ and (f) O on the worn surface of the forged alloy.

擦係数の大きさに影響を与えると考えられるが，詳細につい ては次章で述べる.

Fig. 8 はアルミナボールの摩耗部の二次電子線像である. アルミナボールに $\mathrm{Pt}$ 蒸着を施した後, 観察抢よび分析を行 った. 図中の矢印は運動方向を示している.アルミナボール の摩耗痕は表面上に運動方向に対して直角方向に形成されて おり，その表面は粗いことが分かる．Fig. 9 はアルミナボー ルに抢ける摩耗痕内部の二次電子線像および特性 X 線像で ある。（a）は摩耗痕内部の拡大眓で，(b)-(e)はそれぞれ同 一箇所の $\mathrm{Pt}, \mathrm{Al}, \mathrm{Co}$ および $\mathrm{Cr}$ の特性 $\mathrm{X}$ 線像である. $\mathrm{Pt}$ の 特性 $\mathrm{X}$ 線像より, 蒸着した $\mathrm{Pt}$ が均一に検出されているの で，少なくともこの倍率の表面はボール表面粗さに起因する 特性 X 線強度の変化は無視できると考えられる。このこと を踏をえた上で, 各元素の特性 X 線像に着目する. 主成分 の $\mathrm{Al}$ は最も色濃く写っているが，一部検出されない領域が 存在する.この $\mathrm{Al}$ 未検出の領域に対応して, $\mathrm{Co}, \mathrm{Cr}$ が存 在することが分かる.なお, 図中の元素だけではなく他の元 素についても同様に調べた結果，C，O は全面に対しほぼ均 一に検出されたのに対し，Moはごくわずか検出された．以 上の結果より, 摩耗試験中にアルミナボールには $\mathrm{Co}-\mathrm{Cr}-$
Mo 合金が移着することが分かる.

\section{4 摩擦摩耗試験前後での硬さ変化}

摩擦摩耗試験前後に打ける試料表面の硬さを測定した結果 を Table 2 にまとめる. 試験前のディスク試験片の硬さは Hv383 であったが, 接触荷重 $9.8 \mathrm{~N}$ 打よび $49 \mathrm{~N}$ で摩耗試験 を行った後の摩耗痕内部の硬さは, それぞれ Hv543 および Hv590 まで上昇していた。このように摩耗試験前後で硬さ が上昇すること, さらにより高い荷重での摩耗試験では摩耗 痕内部の硬さの上昇がより大きくなることが分かる。この摩 耗試験後に硬さが上昇するのは, Fig. 2 (b) に示す X 線回折 での結果からも分かるように, 摩耗表面が $\gamma \rightarrow \varepsilon$ のひず誘 起マルテンサイト形成を伴った強加工硬化を起こすことに起 因していると考えられる.

\section{4. 考察}

\subsection{Hertz の接触理論に基づく応力分布解析}

本節では, 本研究での摩擦摩耗試験における接触荷重の増 加による, 接触円表面内抢よび下部領域での応力分布の変化 
について，Hertzの接触理論15) に基づき算出し，これに基づ き摩擦摩耗環境について考察する.

Fig. 10 は次式 (4)-(6)を用いて算出した, 垂直応力 $\left(\sigma_{z}\right)$, 半径方向の応力 $\left(\sigma_{r}\right)$, 円周方向の応力 $\left(\sigma_{\theta}\right)$ 抢よびせん 断応力 $(\tau)$ の分布である.
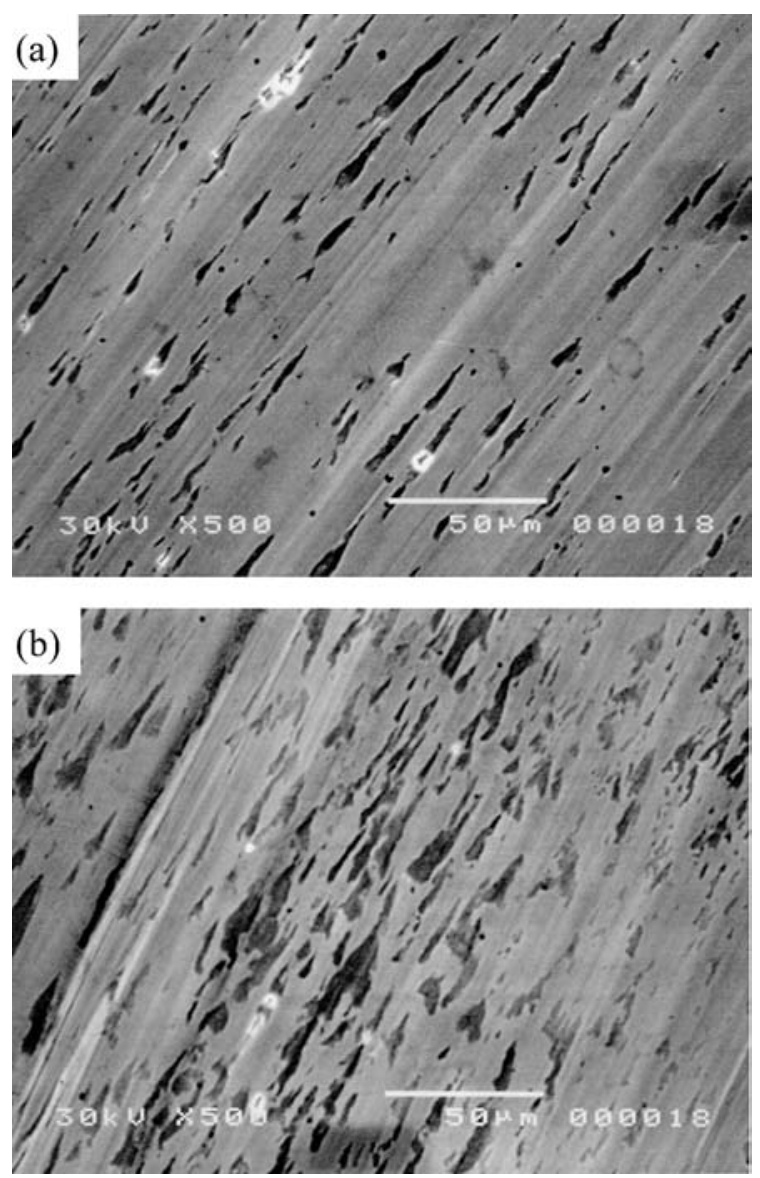

Fig. 7 SEM micrographs of wear scars at the contact load of (a) $9.8 \mathrm{~N}$ and (b) $49 \mathrm{~N}$. $\sigma_{z}=\frac{a^{2}}{a^{2}+z^{2}} P_{\max }$

$\sigma_{r}=\sigma_{\theta}=-\left[\left(1+v_{2}\right) \frac{z}{a}\left(-\frac{\pi}{2}+\frac{a}{z}+\sin -1 \frac{z}{\sqrt{a^{2}+z^{2}}}\right)\right.$

$$
\left.-\frac{a^{2}}{2\left(a^{2}+z^{2}\right)}\right] P_{\max }
$$

$\tau=\frac{\left|\sigma_{z}-\sigma_{r}\right|}{2}$

ここで $z$ は表面からの深さであり， $a$ は接触円半径, $S c$ は接 触面積, $P_{\max }$ は最大接触圧力, $\bar{P}$ は平均接触圧力である. $a$, $S c, P_{\max }, \bar{P}$ は次式 ( 7 )-(10)を用いて算出した.

$$
\begin{aligned}
& a=\left\{\frac{3}{4} W R\left(\frac{1-v_{1}^{2}}{E_{1}}+\frac{1-v_{2}^{2}}{E_{2}}\right)\right\}^{\frac{1}{3}} \\
& S c=\pi a^{2} \\
& P_{\max }=\frac{3 W}{2 \pi a^{2}} \\
& \bar{P}=\frac{W}{\pi a^{2}}=\frac{2}{3} P_{\max }
\end{aligned}
$$

ここでは， $W$ : 荷重 $[\mathrm{N}], R$ : ボール半径 $[\mathrm{m}], v_{1}:$ アルミ ナのポアソン比 $(=0.25), E_{1}:$ アルミナのヤング率 $(=345$ $\mathrm{GPa}), \quad v_{2}: \mathrm{Co}-\mathrm{Cr}-\mathrm{Mo}$ 合金のポアソン比 $(=0.3), E_{2}: \mathrm{Co}-$ $\mathrm{Cr}-\mathrm{Mo}$ 合金のヤング率 $(=230 \mathrm{GPa})$ の值を用いて算出して いる.

着目すべき点は, 最表面から深さ $z \cong 0.5 a$ の箇所に作用 するせん断応力が最大になることである.この最大せん断応 力 $\tau_{\max }$ の值は平均接触圧力 $\bar{P}$ を用いた式(11)で示される.

$$
\tau_{\max }=\left.\frac{\left|\sigma_{z}-\sigma_{r}\right|}{2}\right|_{z \cong 0.5 a} \cong 0.31 P_{\max }=0.465 \bar{P}
$$

Fig. 10 よりボールがディスク試験片にヘルツ接触する場 合, 平均接触圧力 $\bar{P}$ のとき, この深さ $0.5 a$ におけるせん断 応力の大きさは $0.47 \bar{P}$ になり，ここから表面側に向かうに

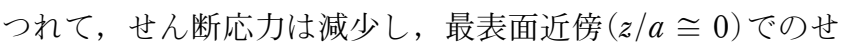
ん断応力 $\tau_{\text {surface }}$ は式 $(12)$ で表される.

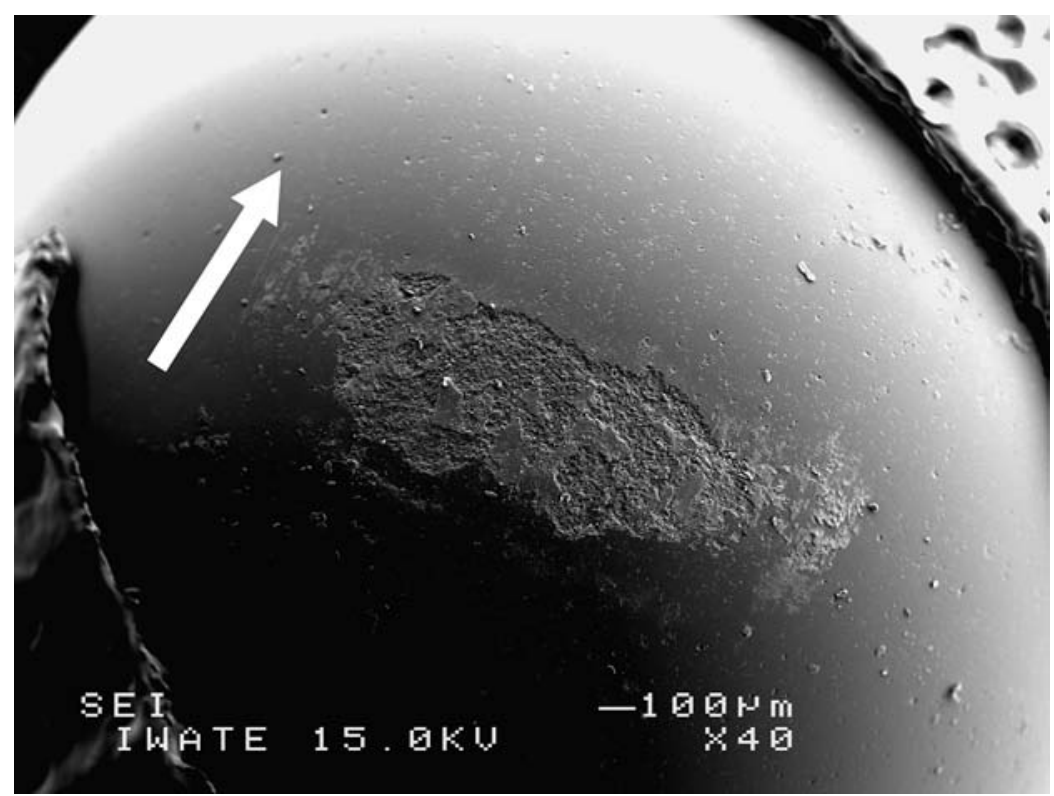

Fig. 8 SEM micrograph of worn surface of the alumina ball. 


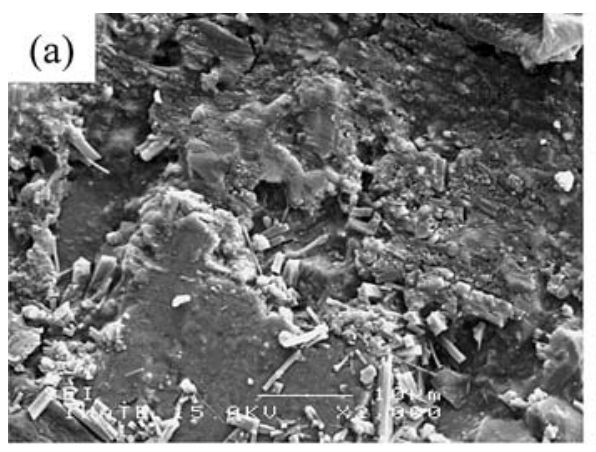

(b) $\mathbf{P t}$

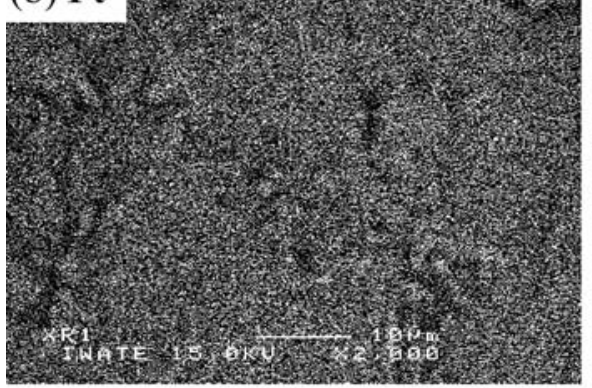

(d) $\mathrm{Co}$

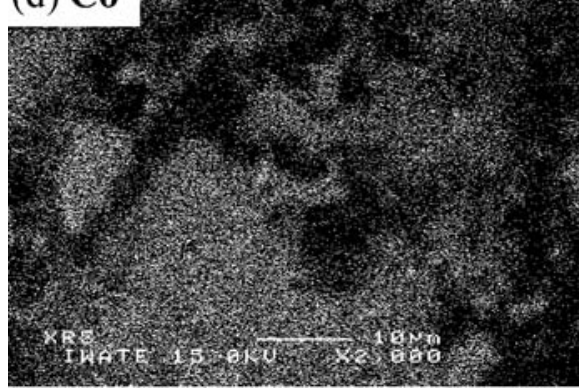

(c) $\mathrm{Al}$

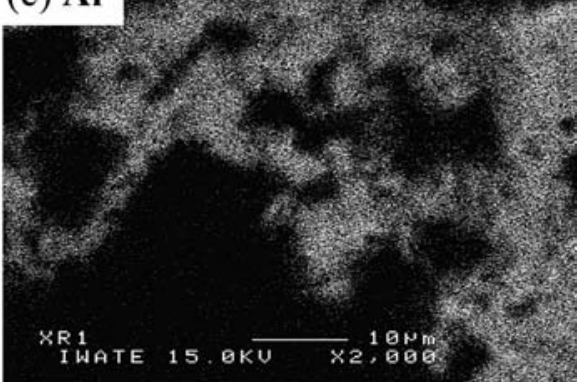

(e) $\mathrm{Cr}$

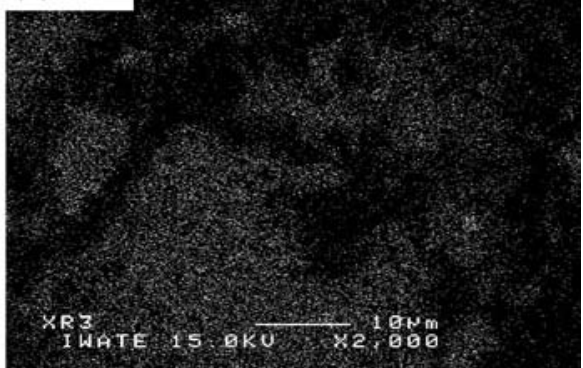

Fig. 9 SEI micrograph (a) and X-ray maps of (b) Pt, (c) Al, (d) Co and (e) Cr on the worn surface of the alumina ball.

Table 2 Micro Vickers hardness of the forged $\mathrm{Co}_{-} \mathrm{Cr}-\mathrm{Mo}$ alloy before and after wear test. (Wear condition: Contact Load 9.8 or $49 \mathrm{~N}$, Distance $10^{4} \mathrm{~m}$, Velocity $0.5 \mathrm{~m} / \mathrm{s}$ ).

\begin{tabular}{cc}
\hline Sample & Hardness $(\mathrm{Hv})$ \\
\hline As-polished surface & 383 \\
After wear test (Contact load 9.8 N) & 543 \\
(Contact load 49 N) & 590 \\
\hline
\end{tabular}

$\tau_{\text {surface }}=\left.\frac{\left|\sigma_{z}-\sigma_{r}\right|}{2}\right|_{z \cong 0.0 a} \cong 0.087 P_{\max }=0.13 \bar{P}$

Fig. 11 は $z / a=0.5,0.4,0.1,0.04,0$ の深さにおけるせん断 応力の接触荷重依存性を示す. 図中の最上段にある曲線は, 式(11)で示される深さ $0.5 a$ におけるせん断応力の荷重依存 性を示す. 一方, 下方の曲線は表面側のせん断応力の接触荷 重依存性を示す。この本鍛造合金の一軸引張試験での降伏応 力 $\sigma_{\mathrm{s}}$ は $590 \mathrm{MPa}$ である ${ }^{9)}$ ので, 最大せん断降伏応力条件 (Tresca の条件) を採用すると, 最大せん断応力 $\tau_{\max }=0.47 \bar{P}$ がこの鍛造合金の $\sigma_{\mathrm{s}}=590 \mathrm{MPa} の 1 / 2$ の $295 \mathrm{MPa}$ に達した とき, 最大せん断応力の生じる接触表面中央下 $0.5 a$ の深さ のところが塑性変形し，それ以下の接触荷重では接触表面お よびその下部の全領域で弾性変形する(完全弾性接触).この

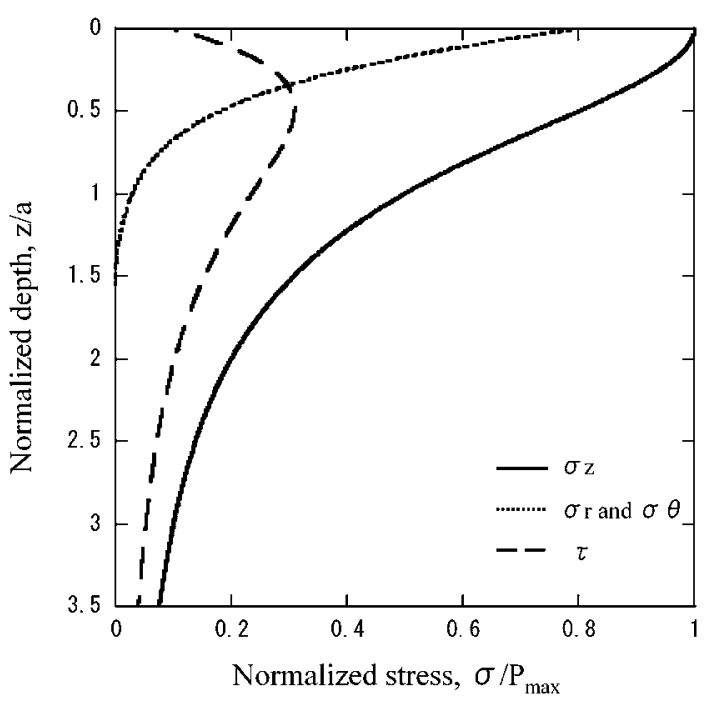

Fig. 10 Stress distribution of contact surface.

ときの接触荷重を完全弾性接触上限荷重 (Upper limit for

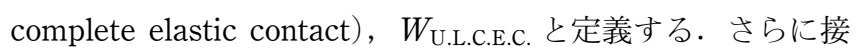
触荷重を増加させると, 深さ $0.5 a$ 以外のところも塑性変形 


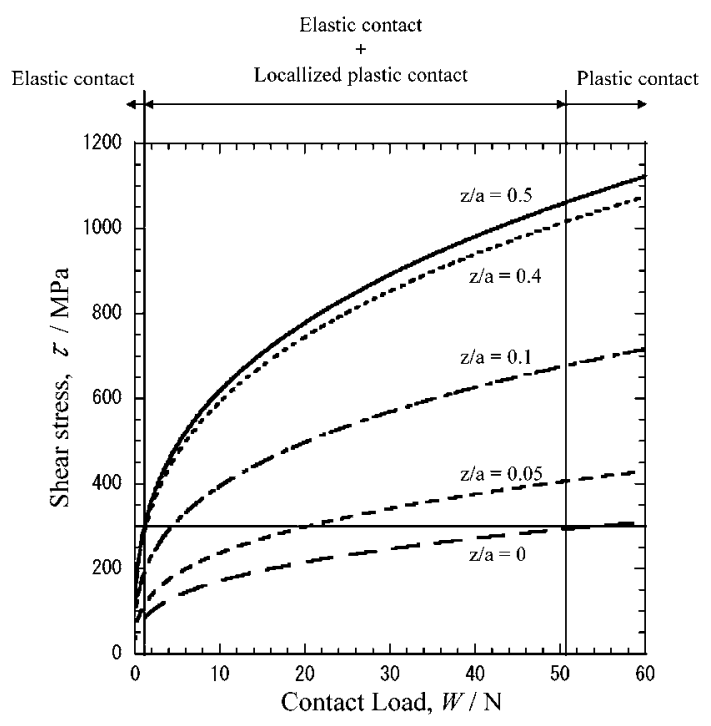

Fig. 11 Shear stress as a function of contact load.

し, 式(12)に示される最表面近傍 $(z / a \cong 0)$ でのせん断応力 $\tau_{\text {surface }}=0.13 \bar{P}$ が $295 \mathrm{MPa}$ に達したとき, ついには接触円表 面近傍内部がすべて塑性変形する(完全塑性接触)，このとき の接触荷重を完全塑性接触下限荷重 (Lower limit for com-

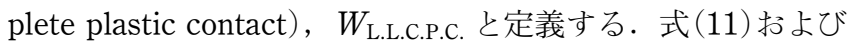

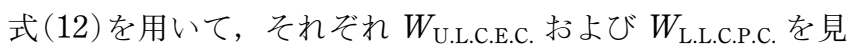
積もった結果， $W_{\text {U.L.C.E.C. }}=1.1 \mathrm{~N}$ 抽よび， $W_{\text {L.L.C.P.C. }}=51.5$ $\mathrm{N}$ と見積もることができる. 本研究では最低接触荷重は 4.9 $\mathrm{N}$ であるので, これは上述の議論より, 弾塑性混合接触状 態の摩擦摩耗環境を与える. 一方, 最大の接触荷重は $49 \mathrm{~N}$ であるが，この場合でも上述の議論より, 弾塑性混合接触状 態の摩擦摩耗環境を与える.ゆえに本研究の試験環境は接触 面下層では局所的に塑性変形領域を含むが，接触表面では弾 性接触状態で摩耗試験を行ったものと判断できる.

\section{2 アルミナ/本鍛造合金の摩耗機構}

アルミナボール/鍛造合金ディスクが弾性接触するときの 摺動面の摩擦摩耗過程を考察する. Fig. 8 より摩耗試験後の アルミナボールに鍛造合金の成分である Co 抢よび C r の移 着が認められた．このCo 抢よび Cr の移着よりアルミナ/本 鍛造合金の間で凝着摩耗が起こることが示唆される. 真実接 触部では両材質表面の原子レベルで互いに力を及ぼし合う (凝着する)ことにより，両材料は結合する. 相手材の摩擦運 動に伴い凝着力より弱い結合部分からせん断破壞して, 凝着 摩耗に至る.アルミナと本鍛造合金では本鍛造合金のせん断 破壊応力が低いため, 本鍛造合金内部で㠜着摩耗を起こし易 いので Fig. 8 に観察されるようなアルミナボールに凝着摩 耗粉の移着が生じたと推測される. 通常, 無潤滑環境中の凝 着摩耗による比摩耗量の概略值は $10^{-6}-10^{-10} \mathrm{~mm}^{2} / \mathrm{N}$ とさ れる ${ }^{16)}$. 本鍛造合金の比摩耗量は $10^{-8} \mathrm{~mm}^{2} / \mathrm{N}$ であること から, アルミナ/本鍛造合金の摩耗機構は真実接触部の凝着 摩耗が支配的であると考えられる。

凝着摩耗はマイルド摩耗とシビア摩耗の形態に大別され る. どちらの摩耗形態になるかは接触荷重, 滑り速度, 雾囲
気等に影響される，一般にシビア摩耗を起こす材料の比摩耗

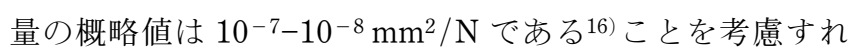
ば, 本研究に扔いては, 比摩耗量に基づく分類では本鍛造合 金は全荷重範囲でシビア摩耗を起こしていると考えられる.

ここで, 接触荷重と凝着摩耗形態の関係について整理す る. 接触荷重の増加は摩耗表面における真実接触面積を増加 させる. 接触荷重が摩耗表面を降伏させる荷重に近づくと, 真実接触部での塑性変形領域が重なるようになる。これによ り, 真実接触部の平均接触圧力と降伏応力とが同程度にな り, 真実接触面積が見かけの接触面積に急激に近づくので, それに伴い摩擦, 摩耗の急激な増加をもたらすと考元られ る. したがって, 接触荷重の増加, 具体的には接触表面が塑 性接触を起こすに十分な接触荷重まで増加すると, マイルド 凝着摩耗からシビア摩耗に遷移することが考えられる.

式(12)より摩耗表面が降伏するための平均接触圧力 (理論 降伏圧力) $\bar{P}_{\text {thys }}$ はと式 (4), (6 ) 抢よび ( 7 )より, $2270 \mathrm{MPa}$ と見積もることができる．したがって $\bar{P}_{\text {thys }}=2270 \mathrm{MPa}$ を与 える荷重, すなわ $51.5 \mathrm{~N}$ 以上の荷重が負荷されるとき, 最 表面近傍で理論上降伏が起こり, マイルド凝着摩耗からシビ ア摩耗に遷移することが考えられる. 本研究の摩耗試験は荷 重条件としては, 最大接触荷重 $49 \mathrm{~N}$ に扔ける平均接触圧力

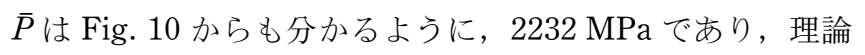
降伏圧力 $\bar{P}_{\text {thys }}=2270 \mathrm{MPa}$ に比べて小さいことから, 荷重条 件としては, 本鍛造合金はマイルド凝着摩耗を起こすと考元 られる. 実際の本鍛造合金の平均降伏圧力 $\bar{P}_{\mathrm{ys}}$ は, 硬さから 知ることができる. 本研究では Table 2 に示されるように, 摩耗試験前のビッカース硬さは Hv383 であり, これは平均 接触圧力に換算すると, $3756 \mathrm{MPa}$ に相当し, 本研究での最 大接触荷重は $49 \mathrm{~N}$ での平均接触圧力 $1418 \mathrm{MPa}$ よりはるか に大きい值であるで, 実測值からも鍛造合金はマイルド摩耗 形態の凝着摩耗を起こすと考えられる. しかし実測される比 摩耗量の值は, 前述したようにシビア摩耗の領域にあり, 上 述の考察が適用されない結果となっている.

そこで，マイルド摩耗を示す接触荷重条件であるにも拘わ らず, 実際の比摩耗量がシビア摩耗領域となる原因を考察す る. マイルド摩耗抽よびシビア摩耗のどちらかに分類される かは荷重だけでなく, 滑り速度, 雾囲気に大きく影響を受け るとされる. また凝着摩耗以外の摩耗機構が共存する可能性 についても考慮する必要がある.

Fig. 5 に示されるように, 摩耗痕内部には幅数 $\mu \mathrm{m}$ のアブ レシブ痕と推測される直線的な溝が多数形成されている。 た摩耗痕内部にはアブレシブ痕以外にも, 数 $\mu \mathrm{m}$ 程度の粒子 が観察される。これらの粒子について特性 X 線像を調べた 結果, Fig. 6 で示される細長い酸化物と類似していた. アブ レシブ痕はこの硬い粒子(摩耗粉)がアルミナ/本鍛造合金の 間に介在する 3 固体間のアブレーションにより形成された と推測される. 一般にアブレシブ摩耗を起こす材料の比摩耗 量の概略值は $10^{-5}-10^{-7} \mathrm{~mm}^{2} / \mathrm{N}$ である ${ }^{16)}$.

Fig. 5 (c)の写真より摩耗痕内部のアブレシブ痕の摩耗痕 全体に対する面積率を計算した結果, 約 $10 \%$ 程度であっ た. そこで摩耗率に対するアブレシブ摩耗の寄与もこの程度 であると考え, 測定して得られた比摩耗量の值(オーダー)が 
$10 \%$ のブレシブ摩耗による寄与 $\left(0.1 \times 10^{-7} \mathrm{~mm}^{2} / \mathrm{N}\right)$ と $90 \%$ のイルド凝着摩耗 $\left(0.9 \times 10^{-9} \mathrm{~mm}^{2} / \mathrm{N}\right)$ との合計とし て算出すると $10^{-8} \mathrm{~mm}^{2} / \mathrm{N}$ のオーダーの比摩耗量となる. これは実際に測定して得られた本鍛造合金の比摩耗量のオ一 ダーである (Fig. 3(b))。このことより，本研究で用いた本 鍛造合金の摩耗形態を考察すると, 凝着摩耗としてはマイル ド摩耗が支配的であると考えられるが，外因的要因ではある ものの，摩耗粉がアルミナ/鍛造合金ディスクに介在して生 じる 3 固体間のアブレーション機構によるアブレシブ摩耗 が副次的に起こっていると考えられる.

本研究では Hertzの接触理論に基づいてディスク試験片 接触面以下に打ける応力状態を考察した. 本研究の試験条件 では接触面ではボールと弾性接触しているが, 最小接触荷重 条件でも表面直下 $0.5 a$ 程度の深さには塑性変形領域を含ん でいることが分かった．このとき接触面付近は弾性変形して いても，表面直下 $0.5 a$ の深さに抢ける任意の一点に着目す れば，接触荷重によるせん断応力で塑性降伏応力以上のせん 断応力の負荷と除荷が周波数 $9.95 \mathrm{~Hz}$ で繰り返し行われてい るとみなせるため, ディスク試験片摩耗表面下の塑性変形部 は疲労破壊を起こす可能性が指摘される. 凝着摩耗を主に起 こす環境でも, 表面下層の疲労破壊が摩耗の原因となること も考えられる. 上述のようにこのディスク試験片内部の応力 状態を考慮すると, このステップはいわゆるデラミネーショ ン摩耗17,18)によって発生した可能性が挙げられる. Fig. 5 (c)に示す摩耗痕内部にはフレーク状摩耗片の他に積層構 造をなすステップが観察され，そしてこのフレーク状摩耗片 はこのステップより剥離する直前のものと推測される。 ま た，このフレーク状摩耗片のようなデラミネーション摩耗粉 は 3 固体間のアブレーションの介在摩耗粉として作用する と考えられる。しかし，この機構を解明するためには，更な る調査が必要である.

\section{3 本鍛造合金に特有な摩擦摩耗過程}

一般に摩耗量 $V$ は式(13)で記述される.

$$
V=K \frac{W L}{H}
$$

ここで, $K$ : 摩耗係数, $W$ : 荷重, $L:$ 滑り距離, $H:$ 硬さ である.式(13)より材料の硬さは耐摩耗性に影響を及ぼす 重要な因子である。そこで硬さに注目して，本鍛造合金の摩 耗特性の特徵的な挙動を考察する.

\subsection{1 接触荷重増加に伴う硬さの上昇および比摩耗量の減} 少

Table 2 で示されるように, 摩耗痕内部の硬さは摩耗して いない領域のそれより大きい。Fig. 2(b)より，本鍛造合金 は摩擦摩耗の進行に伴いひず久誘起マルテンサイト変態を起 こすことが分かった。これは本鍛造合金では， $\mathrm{Ni}, \mathrm{C}$ を多く 含んだ Co-Cr-Mo 合金に比べて積層欠陷エネルギーが低く, $\gamma$ 相が不安定であることに起因する10).

塑性変形に伴う形成されるひずみ誘起マルテンサイトは, 本鍛造合金の高い加工硬化性の主要因となっている．このと き, ひずみ誘起マルテンサイトは接触荷重およびひずみ量に 応じてその量が増加する ${ }^{12,20)}$. したがって本鍛造合金では摩
耗環境で, ひずみ誘起マルテンサイト変態を伴った強加工硬 化層が形成されて硬さ $H$ が上昇するので, 式(13)より摩耗 率の上昇が抑制される機構が働くと考えられる.

次に, 接触荷重の増加に伴う比摩耗量の減少について考察 する. 式(13)より比摩耗量 $\omega_{\mathrm{s}}$ は式(14)で示される.

$$
\omega_{\mathrm{s}}=\frac{V}{W L}=\frac{K}{H}
$$

式(14)の比摩耗量は接触荷重の増加と共に $H$ が増加するこ とによって減少することを示唆するが，実際の実験結果 (Fig. 3(b)) はこの予想と一致して, 接触荷重の増加と共に 比摩耗量は減少する.

以上をまとめると，接触荷重の増加によって促進されるひ ずみ誘起マルテンサイト変態は硬さを上昇させることによ り，摩耗率の増加を抑制し，その結果，比摩耗量を減少させ ると考えられる。 また Cooper らの摩耗試験結果に比べ，本 鍛造合金の比摩耗量が少なかったのは，本鍛造合金には積層 欠陥エネルギーを増大させる $\mathrm{Ni}, \mathrm{C}$ 量が少ないので，マルテ ンサイト変態が起きやすく, 硬さの上昇が大きいためと考え られる。

\subsection{2 摩擦酸化による摩耗環境の変化}

摩擦係数の減少から, 荷重増加に伴い摩耗環境が変化する ことが示唆される. 摩擦係数 $\mu$ の減少は摩擦面の清浄度 $k$ を用いて式(15)で説明される21).

$$
\mu=\frac{1}{\sqrt{\alpha\left(k^{-2}-1\right)}}
$$

ここで清浄度 $k(0<k<1)$ は摩擦面の清浄さを表す数值で ある.式(15)は， $k$ が 1 に近づくほど表面の污染が少なく完 全な凝着が生じやすいため, $\mu$ は増大する. 一方, $k$ が小さ くなるほど表面が污染され，その分，真実接触部の凝着強さ が減少するため， $\mu$ は減少することを意味する.

摩耗痕内部には Cr, Mo rich の酸化物が存在し, この酸化 物はアルミナボールの摩擦摩耗によって生成されたものであ る. 通常 $\mathrm{Co}-\mathrm{Cr}-\mathrm{Mo}$ 合金の表面は $\mathrm{Cr}$ および Mo を含む酸化 物を形成している，摩耗過程において，ボールとディスク間 でこの酸化物の移着が繰り返し行われる。ある程度成長した 移着酸化物は $\mathrm{Cr}$ および Mo の複合酸化物となる ${ }^{22)}$. さら に，成長した移着酸化物は結果的に圧縮された摩耗粉とな り，摩耗痕内に存在する. Fig. 6 で示される Cr および Mo を含む複合酸化物は表面を污染するものであり， $k$ を減少さ せると考えられる.

\subsection{3 摩耗面の硬さの影響}

硬さの上昇は摩擦係数の低下を促進する表面酸化物の安定 性にも影響を及ぼす。酸化物の強度が下地金属より高い場合 や接触荷重が高い場合，下地金属が塑性変形を起こす．表面 酸化物の変形が下地金属の変形に追従できなくなったとき, 酸化物は破壊し下地金属表面から剥離し摩耗粉として排出さ れる. 酸化物の破壊後は下地金属との接触が予想されるの で, 結果的に摩擦係数は増加することはあっても低下するこ とは考え難い、本鍛造合金の場合, ひずみ誘起マルテンサイ 卜変態の進行に伴い硬さが増加するため, 下地金属の塑性変 形が起こりにくく，アルミナボールが酸化皮膜表面上を滑る 機会が多くなると推測される. 本研究で接触荷重の増加に伴 
い，摩擦係数が緩やかな減少傾向を示したことは，ひずみ誘 起マルテンサイト相が表面酸化物の安定な土台として機能す ることを示唆している。

\section{5. 結言}

アルミナボールを使用したボールオンディスク型摩擦・摩 耗試験を通して，通常の高 $\mathrm{Ni}$ および高 $\mathrm{C}$ の $\mathrm{Co}-29 \mathrm{Cr}-6 \mathrm{Mo}$ 合金に比べて低い積層欠陥エネルギーを有する $\mathrm{Ni}$ および C 無添加 Co-29Cr-6Mo 鍛造合金 (以下, 簡単に本鍛造合金と 称する)の乾式摩耗機構および特性を調べた. 得られた結果 は以下のように要約される.

（1）本鍛造合金の比摩耗量および摩擦係数は，接触荷重の 増加に伴い減少する.

（2）本鍛造合金の摩耗率および比摩耗量は, Stellite 6B よ り小さいことから，本鍛造合金の高耐摩耗性が示された.

(3) 摩擦・摩耗試験前後におけるX線回折パターンを比 較した結果, 本鍛造合金では, 摩耗プロセスの進行に伴い, 低積層欠陥エネルギーに起因するひずみ誘起マルテンサイト 変態を起こす．マルテンサイト変態に伴い摩耗面の硬さが著 しく増大する.

（4）Hertzの接触理論を用いて考察した結果，本鍛造合金 とアルミナボールの接触表面ではすべての接触荷重条件で弾 性接触しており, マイルド凝着摩耗を起こす応力環境である ことが分かった. マイルド凝着摩耗以外の摩耗機構として, 本鍛造合金の摩耗痕観察に基づいてアブレシブ摩耗の寄与 (アブレシブ痕の面積率)を見積もり, 全体の比摩耗量を計算 した結果, $10^{-8} \mathrm{~mm}^{2} / \mathrm{N}$ のオーダーと求まる.これは実測し た比摩耗量のオーダーと一致しており,このことより, 本鍛 造合金のアルミナボールによる主要な摩耗機構はマイルド凝 着摩耗であり, 外因的に摩耗粉により生じるアブレシブ摩耗 が共存する摩耗機構が考えられる.

本研究の遂行にあたって, 岩手大学工学部 藤沼重雄氏,
岩手県工業技術センター 園田哲也氏, 飯村 崇氏に感謝い たします。な㧍, 本研究は都市エリア産学官連携促進事業の 助成の下に行われた.

文献

1) W. Rostoker, C. W. Pretzel and J. O. Galante: J. Biomed. Mater. Res. 8(1974) 407-419.

2) J. H. Dumbleton: Tribology of Natural and Artificial Joints, (Elsevier, 1981) pp. 223-226.

3) H. Mckellp, I. Clarke, K. Markorf and H. Amustutz: J. Biomed. Mater. Res. 15 (1981) 619-653.

4) J. Berzen, H. W. Brinkrant and G. Braum: Br. Polym. J. 10 (1978) 281-287.

5) J. R. Atkinson, J. M. Dowling and R. Z. Cicek: Biomaterials 1 (1980) 89-96.

6) H. Yokozeki, I. Katayama, K. Nishioka, M. Kinoshita and S. Nishiyama: J. Dermatol 19(1992) 964-967.

7) S. Artik, C. von Vultee, E. Gleichmann, T. Schwarz and P. Griem: The Journal of Immunology 136 (1999) 1143-1152.

8) Annual Book of ASTM Standards, Vol. 13.01, Medical Devices: (Emergency Medical Services, 1996) 4-6.

9) A. Chiba, K. Kumagai, H. Takeda and N. Nomura: Materials Science Forum 475-479 (2005) 2317-2322.

10) C. T. Sims, N. S. Stoloff and W. C. Hagel: Super Alloys II, (High Temperature Materials for Aerospace and Industrial, New York, 1987) pp. 135-163.

11) D. K. Chaudhuri, D. Xie and A. N. Lakshmanan: Wear 209(1997) 140-152.

12) P. Huang and H. F. Lopez: Materials Letters 39 (1999) 244-248.

13) M. Sage and Ch. Guillaud: Revue de Metallugie, Siderurgy Research Institute (I.R.S.I.D.), XLVII, No. 2 (1950) pp. 139145.

14) C. V. Cooper, C. L. Rollend and D. H. Krouse: Trans. ASME J. Tribology 111(1989) 668-674.

15) H. Hertz: J. Reine und Angew Math. 92(1881) 156-171.

16) T. H. C. Childs: Tribology Int. 13(1980) 285-293.

17) N. P. Suh: Wear 25(1973) 111-124.

18) N. P. Suh: Wear 44(1977) 1-16.

19) J. F. Archard: J. Appl. Phys. 24(1953) 981-988.

20) P. Huang and H. F. Lopez: Materials Science and Technology 15 (1999) 157-164.

21) F. P. Bowden and D. Tabor: The Friction and Lubrication of Solid, Pt. 2, (Oxford University Press, Oxford, 1964) pp. 345348.

22) D. A. Rigney, L. H. Chen and M. G. S. Naylor: Wear $\mathbf{1 0 0}$ (1984) 195-219. 